Review

\title{
Immunology and skin cancer
}

\author{
Andreea Grosu-Bularda *,1, Luana Lăzărescu ${ }^{1}$, Alexandru Stoian', Ioan Lascăr ${ }^{1,2}$
}

${ }^{1}$ Clinic of Plastic Surgery, Aesthetic and Reconstructive Microsurgery, Emergency Clinical Hospital

Bucharest, Romania; " "Carol Davila" University of Medicine and Pharmacy, Bucharest, Romania

\begin{abstract}
Skin cancer represents the most frequent type of human malignancy. Skin poses an important immunologic role, therefore also the correlation between skin cancer development and immunologic mechanisms are intensely studied. These aspects are of the utmost importance in patients requiring immunosuppressive therapy as transplant recipients or immunologic disorders. Cancer development after organ transplantation is the result of intense intercommunication between immunological and nonimmunological factors. Non-immunologic risk factors like individual predisposition, sun and environmental exposure are a contributing part to the skin neoplasia incidence. In addition, continuous exposure to immunosuppressive medication is closely linked to the development of the new malignancy. A similar situation is encountered in autoimmune diseases, those patients having an increased risk of skin cancer, especially squamous cell carcinoma. Immunotherapy shows promising results and encourages further studies in this direction. Also, an important aspect is to support preventive strategies in patients with high risk of skin cancer development.
\end{abstract}

Keywords: skin cancer; immune response; immunosuppressant therapy; transplant; autoimmune disease

\section{Introduction}

Skin cancer represents the most frequent type of human malignancy. The tumors with keratinocytic origin (non-melanoma)-Basal Cell Carcinoma (BCC) and Squamous Cell Carcinoma (SCC) are the most common types, having for example in United States an annual incidence of more than 4 million cases $[1,2]$. With their increasing incidence, those malignancies affect in US more people than all other types of cancer together, representing a significant problem for the public health system [3]. Therefore, a rigorous understanding of skin cancer mechanisms is

Received: August 2018; Accepted after review: September 2018; Published: September 2018.

${ }^{*}$ Corresponding author: Andreea Grosu-Bularda, Emergency Clinical Hospital, Calea Floreasca no. 8, Bucharest, Romania. Tel: 0040722456608.

Email: andreeabularda@gmail.com mandatory to develop adequate preventive and therapeutic strategies with efficient allocation of medical resources.

Recently, an increased preoccupation in international research focuses on study the implication of immune system in etiology and evolution of skin cancer in order to develop new therapeutic options [2].

\section{Skin Cancer Classification}

Multiple skin cancer entities have been described, depending on the tumor cells of origin, as we can see in Table 1 (Skin tumors classification according to World Health Organization WHO, 2018) [4, 5].

Non-melanoma cutaneous cancer comprises around $30 \%$ of all malignancy cases with an annual incidence in continuous rising [6]. The most frequent type of skin cancer $(75-80 \%$ of cases) and also the most common of all cancers in humans is 
represented by the basal cell carcinoma. The anatomic regions usually affected by BCC are the head and neck (70-80\%), followed by the trunk (approximately 25\%) and perineum region [7].

Table 1. Skin tumors classification

\begin{tabular}{|c|c|}
\hline Type of tumor relating to origin & Representative tumors \\
\hline $\begin{array}{l}\text { Keratinocytic/Epidermal (Non- } \\
\text { melanoma) }\end{array}$ & $\begin{array}{l}\text { Basal cell carcinoma } \\
\text { Squamos cell carcinoma } \\
\text { Squamous cell carcinoma in situ (Bowen disease) } \\
\text { Merkel cell carcinoma }\end{array}$ \\
\hline Melanocytic & Malignant melanoma \\
\hline Adnexal & $\begin{array}{l}\text { Malignant tumours with eccrine and apocrine differentiation } \\
\text { Malignant tumours with follicular differentiation } \\
\text { Sebaceous carcinoma }\end{array}$ \\
\hline Lympho-hematologic & $\begin{array}{l}\text { Mycosis fungoides } \\
\text { CD30+ T-cell lymphoproliferative disorders } \\
\text { Skin T-cell leukaemia/lymphomas (primary or secondary) } \\
\text { Skin B-cell lymphomas (primary or secondary) } \\
\text { T-lymphoblastic and B-lymphoblastic leukaemia } \\
\text { Blastic plasmacytoid dendritic cell neoplasm } \\
\text { Skin determination in myeloid leukaemia }\end{array}$ \\
\hline Neural & Malignant peripheral nerve sheath tumour \\
\hline Soft tissue & $\begin{array}{l}\text { Liposarcoma } \\
\text { Fibroblastic, myofibroblastic and fibrohistiocytic malignant tumours } \\
\text { Leiomyosarcoma } \\
\text { Skin angiosarcoma } \\
\text { Kaposi sarcoma }\end{array}$ \\
\hline Uncertain differentiation & $\begin{array}{l}\text { Pleomorphic dermal sarcoma } \\
\text { Epithelioid sarcoma } \\
\text { Myxo-fibrosarcoma } \\
\text { Dermal clear cell sarcoma } \\
\text { Ewing sarcoma }\end{array}$ \\
\hline Inherited syndromes & $\begin{array}{l}\text { Familial melanoma } \\
\text { Gorlin syndrome (Naevoid basal cell carcinoma syndrome) } \\
\text { Skin cancers on Xeroderma pigmentosum } \\
\text { Muir-Torre syndrome }\end{array}$ \\
\hline
\end{tabular}

The second most common skin cancer type, after BCC, is squamous cell carcinoma, with around one million annual cases in US. This type of cancer may develop on healthy tissue or on previous specific conditions like actinic keratosis or an old burn scar (Marjolin ulcer). Risk factors associated with SCC development are: UV radiation exposure, light skin patients, elderly, male gender, chronic lesions, radiation therapy, presence of oncogenic viruses likes HPV, environmental exposures (arsenic) and immunosuppression $[6,8,9]$. It is a known fact that immunesuppressive treatments, physical or pharmacological, determine an increased risk of malignancies compared to general population, suggesting the involvement of immune system alterations in skin cancer development and progression [10].

Malignant melanoma is recognized as the most lethal type of skin cancer, bearing a significant burden for health system. Unlike other malignancies, melanoma affects younger, socially active patients with a median diagnostic age of 57 years. Both genetic and environmental factors are associated with cutaneous melanoma development. Despite ongoing research for promoting new therapeutic strategies, for patients with advanced disease the prognosis remains poor [11].

In general population, the least frequent types of skin cancer are cutaneous lymphoma, 
Kaposi sarcoma, Merkel cell carcinoma, skin adnexal tumors and skin sarcoma [12].

Merkel cell carcinoma-a neuroendocrine epidermal tumor- is a rare but very aggressive type of skin cancer with a very high recurrence risk and metastasizing potential, with higher incidence in the past decades. It is related to Merkel cell polyomavirus in the majority of cases, but also other risk factors as advanced age, UV exposure and immunosuppressant therapy were mentioned [13].

\section{Immunological mechanisms involved in skin cancer}

It is certain fact that skin represents a key player of the immune system. During the last five decades, researchers analyzed the immunologic patways involving cutaneous components. Four immunologic models were described, synthetised in Table $2[14,15]$.

Table 2. Skin immunologic models

\begin{tabular}{lcl}
\hline \multicolumn{1}{c}{ Immunologic model } & $\begin{array}{c}\text { Year of } \\
\text { introduction }\end{array}$ & \multicolumn{1}{c}{ Concept Description } \\
\hline $\begin{array}{l}\text { SALT(Skin-associated } \\
\text { lymphoid tissues) }\end{array}$ & 1983 & $\begin{array}{l}\text { - skin immune surveillance is based on interactions between } \\
\text { keratinocytes, Langerhans cells, the presence of lymph nodes and } \\
\text { immunocompetent lymphocytes }\end{array}$ \\
SIS(Skin immune system) & 1986 & $\begin{array}{l}\text { - includes all components of the normal skin involved in complex immune } \\
\text { responses } \\
\text { - ensure both cellular and humoral responses } \\
\text { - situated in small vassels of papillary dermis }\end{array}$ \\
$\begin{array}{l}\text { DMU(Dermal microvascular } \\
\text { unit) }\end{array}$ & 1989 & $\begin{array}{l}\text { - includes all components of immne reactivity } \\
\text { - involved fibroblasts which interacts with epidermal components } \\
\text { DIS(Dermal immune system) }\end{array}$ \\
\hline
\end{tabular}

Table 3. Skin immunologic constituents Adapted by permission from Springer Nature: Bos JD, Luiten RM. Skin Immune System. In: Stockfleth E, Ulrich C. (Eds) Skin Cancer after Organ Transplantation. Cancer Treatment and Research, vol 146. Springer, Boston, MA, 2009; License Number: 4424231400954.

\begin{tabular}{lcccc}
\hline & SALT & SIS & DMU & DIS \\
\hline Coagulation/fibrinolysis system & - & + & - & - \\
\hline Complement factors & - & + & - & - \\
\hline Cytokine network & - & + & - & + \\
\hline Dermal T lymphocytes & - & + & + & + \\
\hline Eicosanoids & - & + & - & - \\
\hline Epidermal T lymphocytes & + & + & - & - \\
\hline Fibroblasts & - & - & - & + \\
\hline Free radicals & - & + & - & - \\
\hline Granulocytes & - & + & - & - \\
\hline Keratinocytes & + & + & - & - \\
\hline Langerhans' cells & + & + & - & - \\
\hline Lymphatic endothelial cells & + & + & - & - \\
\hline Mast cells & - & + & + & + \\
\hline Monocytes/macrophages & - & + & + & + \\
\hline Neuropeptides & - & + & - & + \\
\hline Secretory immunoglobulins & - & + & - & - \\
\hline Skin draining lymph nodes & + & - & - & - \\
\hline Tissue dendritic cells & - & + & + & + \\
\hline Vascular endothelial cells & + & + & + & + \\
\hline
\end{tabular}


The concept of cancer immunosurveillance was introduced by Burnet in 1957 and served as a starting point for the more recent cancer immunoediting approach. Trough cancer immunoediting the immune system interacts with developing tumors, sculpting them as an ongoing process including three phases: elimination phase, equilibrium and escape phase, illustrated further in Figure 1 [2, 16, 17].

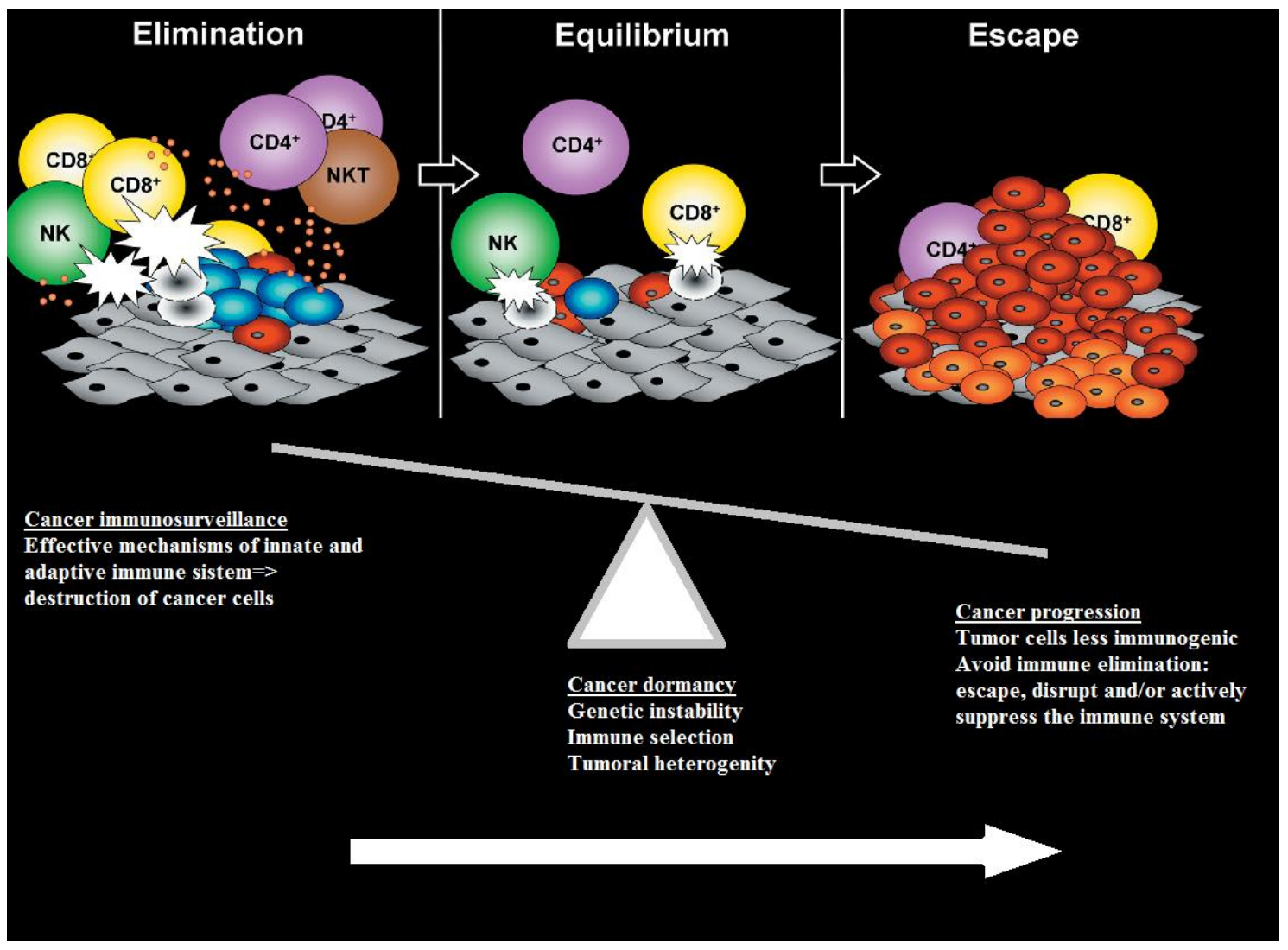

Fig. 1. Phases of cancer immunoediting. Adapted by permission from Springer Nature: Dunn GP, Bruce AT, Ikeda H, Old LJ, Schreiber RD. Cancer immunoediting: from immunosurveillance to tumor escape. Nat Immunol 2002; 3 (11):991-8. License Number: 4427771257332

\section{Clinical implications \\ Skin cancers in transplant patients}

In the last decades the field of organ transplantation developed significantly due to the improvements of surgical protocols and also more efficient immunosuppressive therapies [18].

Annual reports available on Global Observatory on Donation and Transplantation (GODT) for year of 2015 presents the following data: a total of 126,670 organs were transplanted in 2014, from which two thirds $(84,347)$ were renal transplant, $22 \%$ were liver transplants and the rest of $11.5 \%$ included heart, lung, pancreas and small bowel transplant [19].
A recent therapeutic entity is represented by the vascularized composite allotransplantation, including non-vital allograft transplantation like upper and lower limbs, face, larynx and trachea, abdominal wall, penis and uterus transplantation. Those procedures are not life-saving like solid organ transplant and they are performed for functional reconstruction and improvement in quality of life of patients with complex soft tissue defects and specific lost functions, impossible to restore with conventional therapeutic strategies [20, 21].

The limitation on an even more extensive use of transplantation procedures as standard therapeutic options for a large panel of diseases is represented by the immunological 
considerations. Lifelong immunosuppression exposes the transplant patients to severe complications including systemic disorders (cardiovascular, renal, diabetes mellitus), infections and malignancies. Cancers developed in transplant patients are often more aggressive in comparison with general population $[22,23]$.

Carcinogenesis in transplant patients recognizes an association between immunological and non-immunological risk factors. Non-immunological cancer risk factors encountered in general population (gender, advanced age, smoking, sun and radiation exposure, environmental exposure) interacts with cumulative effects of immunosuppressant therapy [24].

Researchers showed also that there are particular viral infections that are clearly connected to specific types of cancer. The following associations have been noted: human herpes virus 8 and Kaposi's sarcoma, human papilloma virus (HPV) and epithelial cancers (skin and non-skin carcinoma). The mechanism of these viral infections consists of the ability of controlling cell cycle and division, escape from apoptosis, supporting transformation and cell-growth. Persistent immunosuppression is the most important risk factor for viral infections-linked malignancies $[24,25]$.

The geographic regions are also a very important factor in determining the type and frequency of neoplasia, creating a wide variance. Therefore, the variables between geographic provenience consist in the following: skin phototype, sun exposure and viral infections prevalence. The association between sun exposure and skin malignancies is present in both the general population as well as in post-transplant patients and it is very frequent in Australia and in the fair-skinned Caucasians and very rare in the Asiatic population $[23,24]$.

Skin cancers represent the most common malignancies associated with transplantation, affecting more than half of the white race transplanted patients, observing an increasing incidence parallel with immunosuppressive therapy duration; more than $90 \%$ of those skin tumors include squamous and basal cell carcinomas [23, 26].

Each solid organ expresses different immunogenicity when it is allotransplanted, for example heart transplant recipients need higher immunosuppression level comparing with other organs [23]. Liver is considered an immune privileged organ, even clinical transplant tolerance with no need for immunosuppressant therapy being reported in some patients [27].

Unlike solid organs, vascularized composite allografts (VCA) contain histological heterogeneous tissues (skin, muscle, tendons, fat, bone, nerves, blood vessels, lymph nodes) expressing different levels of immunogenicity. The immunosuppressive regimes are similar with kidney transplant, with triple therapy including Tacrolimus, Mycophenolate mofetil (MMF) and corticosteroids [28, 29].

Recent findings in VCA field promoted the concept of "split rejection": the various components of the allograft may reject in distinct moment and intensity, suggesting a continuous need for immunologic monitoring of the graft in order to apply a prompt therapy [30].

Immunologic instability with multiple rejection episodes, inappropriately treated, lead to chronic rejection with risk of graft loss and also difficulties in treatment of successive rejection episodes. Aggressive immunesuppressive regimens administered for protecting the allograft increase considerably the risk of complications including malignancies [30-32].

Definitely, continuous exposure to immunosuppressive medication is closely linked to the development of the new malignancies in transplanted patients, each type of immunosuppressant having a different risk in cancer development as we can see in Table 4 [33].

The most frequent association with skin cancers that has been observed is exposure to a high regimen of cyclosporin $A$ or exposure to a combination of cyclosporine $A$ and azathioprine (both recognized as group I carcinogens) [34]. 
Table 4. Interaction between immunosuppressant medication and skin cancer

\begin{tabular}{|c|c|c|}
\hline Immunosuppressive agent & Mechanism of action & Skin cancer involvement \\
\hline $\begin{array}{l}\text { Glucocorticoids } \\
\text { (Prednisolone) }\end{array}$ & $\begin{array}{l}\text { Blocks: IL-1,-2,-3,-4,-6; TNF- } \alpha \text {; } \\
\text { Interferon- } \gamma \text {. } \\
\text { Inhibits: phospholipase A2; } \\
\text { arachidonic acid cascade }\end{array}$ & No evidence of directly carcinogenic side effect \\
\hline $\begin{array}{l}\text { Calcineurin inhibitor } \\
\text { (Cyclosporin) }\end{array}$ & T-cell signaling inhibition & $\begin{array}{l}\uparrow \text { risk of keratinocyte skin cancer } \\
\text { Cyclosporine }+ \text { Azathioprine }=\uparrow \text { risk in } \\
\text { transplanted patients for skin malignancy } \\
\text { High prevalence of cutaneous dysplasia } \\
\text { Mutagenic effect-deficient repair of damaged } \\
\text { DNA; p53 mutations } \\
\text { Promote cancer progression (cell culture and } \\
\text { animal studies) }\end{array}$ \\
\hline Azathioprine & $\begin{array}{l}\text { Immunosuppressive effect - } \\
\text { adding 6-TG into DNA } \\
\text { Deficient activated T-cell } \\
\text { pathways signaling } \\
\text { Further } \uparrow \text { of DNA oxidative } \\
\text { stress after UVA exposure }\end{array}$ & $\begin{array}{l}\text { Carcinogenic and immunosuppressive potential } \\
=>\text { cutaneous cell carcinoma }\end{array}$ \\
\hline $\begin{array}{l}\text { mTor Inhibitors/Proliferation } \\
\text { Signal Inhibitors } \\
\text { (Rapamycin - Sirolimus) }\end{array}$ & $\begin{array}{l}\text { Inhibition of mTor pathway } \\
\text { Altered protein synthesis }\end{array}$ & $\begin{array}{l}\downarrow \text { the incidence of non-melanoma skin cancer } \\
\text { risk in transplant recipients } \\
\text { Induced remission of non-melanoma skin } \\
\text { cancer in renal transplant patients }\end{array}$ \\
\hline
\end{tabular}

\section{Skin cancers in autoimmune diseases}

Lupus erythematosus, dermatomyositis, scleroderma and Sjögren syndrome are the most frequent autoimmune connective tissue diseases [35]. The main causes for the connection between the autoimmune connective tissue diseases and tumors, that could increase the probability of developing skin cancer, imply the damaged immune system, immunosuppressant therapy persistent skin inflammation, higher predisposition to viral infections, as well as additional causes like smoking, ultraviolet radiation exposure, white race and advanced age [35].

The most prevalent skin tumor in lupus erythematosus is squamous cell carcinoma, and a few cases of melanoma and basal cell carcinoma have been outlined. SCC is considered also a complication of discoid lupus erythematosus, with an estimated range from $2.3 \%$ to $3.3 \%[35,36]$.

Scleroderma is also an autoimmune condition associated with higher risk of malignancy. Patients presenting the diffuse cutaneous form of systemic sclerosis, increased age and female gender have increased malignancy risk [37, 38].

In scleroderma, the most frequent cutaneous malignancy is squamous cell carcinoma, in patients with systemic disease or particularly in cases of pansclerotic morphea, when SCC presents recurrences and resistance to treatment. The cancer risk is attributed to chronic ulcers, persistent inflammation, abnormal scaring, and immunosuppressant treatment. The most frequent sites of squamous cell carcinoma associated to scleroderma are legs, feet and scalp [35, 38].

Dermatomyositis is a systemic chronic autoimmune disease, with multifactorial etiology, but also it was observed as a paraneoplastic phenomenon. Requiring lifelong immunosuppression, dermatomyositis increases the patient malignancy risk. Association with malignant melanoma was reported in the metastatic stages and association of dermatomyositis as paraneoplastic phenomenon in melanoma patients determines a very poor prognosis $[35$, 39]. 
Sjögren's syndrome patients also have high cancer incidence. In a study reported by Lazarus et al. on 112 patients suffering by primary Sjögren's syndrome, lymphoma was the most frequent malignancy, followed by breast cancer and melanoma [40, 41].

A few cases were mentioned in the literature regarding occurrence of primary cutaneous lymphomas in patients with Sjögren's syndrome, including $B$ and $T$ cell lymphomas and cutaneous lgGk plasmocytoma [35].

A study conducted by Leung et al. showed an enhanced risk of non-melanoma skin cancer in patients on long-term immunosuppressive therapy for autoimmune hepatitis [42].

Also, strong associations were observed between psoriasis and T-cell lymphomas, Kaposi sarcoma and ulcerative colitis, sarcoma with Graves disease, rheumatoid arthritis with Merkel cell carcinoma [43].

Nitsan et al. reported a case of Mycosis fungoides development on face and left trunk in a 53 years old woman treated for her relapsing-remitting multiple sclerosis with Fingolimod-a sphingosine-1-phosphate (S1P) receptor modulator [44].

Summarizing, patients with autoimmune disorders have an increased risk of developing cutaneous neoplasia, especially squamous cell carcinoma [35].

Avoiding sun exposure, screening and monitoring of skin lesions in autoimmune disorders represent the means for guiding optimal skin cancer screening strategy, but further studies are needed in this direction [42].

\section{Immunotherapy for skin cancer}

The first scientific proof of using immunotherapy for cancer dates back from 1891, when William Coley placed into inoperable tumors streptococcal bacteria to induce an immune response $[45,46]$.

After years in which this therapeutic option was viewed with disbelief, the 1990s brought new insights regarding cancer immunotherapy. Immunogenic cancer antigens were detected, which encouraged the idea of immune system implication, moreover activated dendritic cells are able to induce specific tumor T-cell in order to limit melanoma metastasis [47-49].

From all skin cancers, melanoma has the privilege to be the most studied in terms of immunotherapy. IFN and IL-2 have been used intensively as adjuvant for advanced melanoma, but unfortunately disease-free survival is still a hard goal to achieve [50-52].

Another study found that sentinel node metastasis and ulcerated form of melanoma benefit the most form IFN- $\alpha-2 b$ treatment [53]. High doses of IL-2 (HD IL-2) had moderate results, with mild benefit for metastatic melanoma. Due to the side effects and quality of life impairment, HD IL-2 alone failed to impose the medical practice [54]. Association between IL-2 and chemotherapeutic agents as cisplatin or temozolomide led to development of biochemotherapy, also with low overall response rate [55].

By blocking the CTLA-4 receptors from Tcells using specific antibodies (Anti-CTLA-4 antibody- Ipilimumab) it will enhance proliferation of tumor-specific T-cells. Ipilimumab increased the median overall survival which led to the approval by several countries $[56,57]$.

The concept of using vaccines for melanoma treatment was also investigated, but some Phase III trials failed to prove any benefits in the study group $[58,59]$.

Nowadays a significant attention is pointed to personalized medicine and the study of melanoma is not an exception from this fact. Adoptive T-cell therapy means that lymphodepleted patients will benefit from their own processed (amplified/expressed specific antigen receptors) lymphocytes. In some recent clinical trials, the overall clinical response rate was $30 \%$, but patients experienced autoimmune side effects $[60,61]$.

In the field of non-melanoma skin cancer immunotherapy, Imiquimod is the first synthetic agent of immune-response modifier with best clinical outcome. It binds dendritic cell receptors (TLR7, TLR8) and promotes secretion of a wide variety of cytokines. Furthermore, Imiquimod is able to give a positive feedback on NK cells, B lymphocytes and Langerhans cells [62]. It can be used topically in treatment of superficial BCC, smallnodular BCC and in situ SCC [63]. 
Imiquimod is the most successful example of immunotherapeutic agent, especially for inoperable cases or patient concerned with cosmetic result of surgery [64].

\section{Promoting prevention strategies}

Promoting prevention strategies regarding skin cancer development is a major goal when dealing with immunosuppressed patients.

Tapering of immunosuppressant doses, prevention of viral infections and early diagnosis through regular and adequate screening programs before and after transplantation may help decrease the risk of malignancy after transplantation [65].

The sun exposure is a main factor in tumor development and we saw that squamous cell carcinoma is the most frequent cancer in association with organ transplant or autoimmune diseases. Therefore, patients have to avoid sun exposure as much as possible, use lotions with high level of sunprotection factor, wear adequate clothing (large hats or umbrella, long sleeves, long trousers) when performing outdoor working [23].

According to Tunçer Vural et al., immunosuppressed patients (like solid organ transplant recipients) are strongly advised by medical care providers to make regular visits (once or twice a year) for dermatologic examination and education for skin cancers and sun exposure prevention measures, improving their attitude toward the aforementioned factors [66].

$\mathrm{Wu}$ et al. have shown that selfexaminations and dermatologist-performed skin exam of the whole body together with sun protection education can decrease skin cancer morbidity and mortality in solid organ

\section{References}

1. Rogers HW, Weinstock MA, Feldman SR, Coldiron BM. Incidence estimate of nonmelanoma skin cancer (keratinocyte carcinomas) in the US population, 2012. JAMA Dermatol 2015; 151(10):1081-1086.

2. Rangwala S, Tsai KY. Roles of the immune system in skin cancer. Br J Dermatol 2011; 165 (5):953-965. transplant recipients but further longitudinal trials are needed in order to understand the impact of interventions on cutaneous malignancy, morbidity and to optimize the results of the treatment of transplant recipients [67].

Early recognition and ablation of premalignant tumors also help in preventing skin cancers [23].

\section{Conclusions}

Important clinical evidence attests the implication of immune system in development and further evolution of skin cancer. Patient conditions requiring prolonged immunosuppressant therapy like transplant recipients or autoimmune diseases determine an increased malignancy risk, skin cancer (especially non-melanoma tumors: squamous and basal cell carcinomas) being a frequent occurrence in those patients. It is important to understand the relative risk and to identify the causes of the high risk in tumor development in order to decrease the effects of malignancies on the morbidity and mortality in immunosuppressed patients.

Interaction immune system-skin cancer was the base for introducing immunotherapy in the therapeutic panel with good clinical results. Promoting skin cancer preventive strategies represent an important element and life- long follow-up of the patients is mandatory.

\section{Competing interests}

The authors declare that they have no competing interests.

3. Karimkhani $\mathrm{C}$, Boyers $\mathrm{LN}$, Dellavalle $\mathrm{RP}$, Weinstock MA. It's time for "keratinocyte carcinoma" to replace the term "non-melanoma skin cancer". J Am Acad Dermatol 2015; 72(1):186-187.

4. Elder DE, Massi D, Scolyer RA, Willemze R (Eds). WHO Classification of Tumors, 4th Edition, Volume 11; 2018 [http://publications.iarc.fr/Book-And-Report- 
Series/Who-larc-Classification-Of-Tumours available at 09/29/2018]

5. Tai $P, A u$ J. Skin cancer management-updates on Merkel cell carcinoma. Ann Transl Med 2018; 6(14):282.

6. Burton $\mathrm{KA}$, Ashack $\mathrm{KA}$, Khachemoune $\mathrm{A}$. Cutaneous squamous cell carcinoma: A review of high-risk and metastatic disease. Am J Clin Dermatol 2016; 17(5):491-508.

7. Chung S. Basal cell carcinoma. Arch Plast Surg 2012; 39(2):166-170.

8. Gurudutt VV, Genden EM. Cutaneous squamous cell carcinoma of the head and neck. J Skin Cancer 2011; 2011:502723.

9. Que SKT, Zwald FO, Schmults CD. Cutaneous squamous cell carcinoma: Incidence, risk factors, diagnosis, and staging. J Am Acad Dermatol 2018; 78(2):237-247.

10. Gerlini G, Romagnoli P, Pimpinelli N. Skin cancer and immunosuppression. Crit Rev Oncol Hematol 2005; 56(1):127-136.

11. Ali Z, Yousaf N, Larkin J. Melanoma epidemiology, biology and prognosis. EJC Supp/ 2013; 11(2):81-91.

12. Ridky TW. Nonmelanoma skin cancer. J Am Acad Dermatol 2007; 57(3):484-501.

13. Schadendorf D, Lebbé $C$, Zur Hausen A, et al. Merkel cell carcinoma: Epidemiology, prognosis, therapy and unmet medical needs. Eur J Cancer 2017; 71:53-69.

14. Bos JD, Luiten RM. Skin immune system. In: Stockfleth E, Ulrich C (Eds.) Skin cancer after organ transplantation. cancer treatment and research, Volume 146. Boston: Springer; 2009: 45-63.

15. Streilein JW. Skin-associated lymphoid tissues (SALT): origins and functions. $J$ Invest Dermatol 1983; 80(Suppl):12s-16s.

16. Mittal D, Gubin MM, Schreiber RD, Smyth MJ. New insights into cancer immunoediting and its three component phases-elimination, equilibrium and escape. Curr Opin Immunol 2014; 27:16-25.

17. Dunn GP, Bruce AT, Ikeda H, Old LJ, Schreiber RD. Cancer immunoediting: from immunosurveillance to tumor escape. Nat Immunol 2002; 3(11):991-998.

18. Wadström J, Ericzon BG, Halloran PF, et al. Advancing transplantation: new questions, new possibilities in kidney and liver transplantation. Transplantation 2017; 101(Suppl 2S):S1-S41.

19. Organ donation and Transplantation Activities 2015, in Global Database on Donation and Transplantation [http://www.transplantobservatory.org/ available at 09/29/2018]

20. Siemionow M. Vascularized composite allotransplantation: a new concept in musculoskeletal regeneration. J Mater Sci Mater Med 2015; 26(12):266.

21. Diaz-Siso JR, Bueno EM, Sisk GC, Marty FM, Pomahac B, Tullius SG. Vascularized composite tissue allotransplantation - State of the art. Clin Ttransplant 2013; 27(3):330-337.

22. Chapman JR, Webster AC, Wong G. Cancer in the transplant recipient. Cold Spring Harb Perspect Med 2013; 3(7):a015677.

23. Euvrard S, Kanitakis J, Claudy A. Skin cancers after organ transplantation. N Engl J Med 2003; 348(17):1681-1691.

24. Dantal J. De Novo Post-Transplantation Malignancies: Incidence and Risk Factors. In: Stockfleth E, Ulrich C (Eds.) Skin Cancer after Organ Transplantation. Cancer Treatment and Research. Volume 146. Boston: Springer; 2009: 11-21.

25. White MK, Pagano JS, Khalili K. Viruses and human cancers: a long road of discovery of molecular paradigms. Clin Microbiol Rev 2014; 27(3):463-481.

26. Mittal A, Colegio OR. Skin cancers in organ transplant recipients. Am J Transplant 2017; 17(10):2509-2530.

27. Martinez OM, Rosen HR. Basic concepts in transplant immunology. Liver Transpl 2005; 11(4):370-381.

28. Friedman $O$, Carmel $N$, Sela $M$, et al. Immunological and inflammatory mapping of vascularized composite allograft rejection processes in a rat model. PLOS ONE 2017; 12(7):e0181507.

29. Howsare $M$, Jones $C M$, Ramirez AM. Immunosuppression maintenance in vascularized composite allotransplantation: what is just right? Curr Opin Organ Transplant 2017; 22(5):463-469.

30. Sinha I, Pomahac B. Split Rejection in vascularized composite allotransplantation. Eplasty 2013; 13:e53.

31. Gallagher MP, Kelly PJ, Jardine M, et al. Longterm cancer risk of immunosuppressive regimens after kidney transplantation. $J A m$ Soc Nephrol 2010; 21(5):852-858.

32. Morelon E, Petruzzo P, Kanitakis J. Chronic rejection in vascularized composite allotransplantation. Curr Opin Organ Transplant 2018; 23(5):582-591.

33. Perrett CM, Harwood CA, McGregor JM, Karran P. Carcinogenic Mechanisms Related to Immunosuppressive Therapy. In: Stockfleth E, Ulrich C (Eds.) Skin Cancer after Organ Transplantation. Cancer Treatment and Research, Volume 146. Boston: Springer; 2009: 123-132.

34. Coghill AE, Johnson LG, Berg D, Resler AJ, Leca N, Madeleine MM. Immunosuppressive 
medications and squamous cell skin carcinoma: nested case-control study within the Skin Cancer after Organ Transplant (SCOT) cohort. Am J Transplant 2016; 16(2):565-573.

35. Kostaki D, Antonini A, Peris K, Fargnoli MC. Skin cancer risk in autoimmune connective tissue diseases. G Ital Dermatol Venereol 2014; 149(5):567-572.

36. Tao J, Zhang $X$, Guo $N$, et al. Squamous cell carcinoma complicating discoid lupus erythematosus in Chinese patients: review of the literature, 1964-2010. J Am Acad Dermatol 2012; 66(4):695-696.

37. Wooten M. Systemic sclerosis and malignancy: a review of the literature. South Med $J$ 2008; 101(1):59-62.

38. Zeineddine N, Khoury LE, Mosak J. Systemic sclerosis and malignancy: A review of current data. J Clin Med Res 2016; 8(9):625-632.

39. Bogdanov I, Kazandjieva J, Darlenski R, Tsankov N. Dermatomyositis: Current concepts. Clin Dermatol 2018; 36(4):450-458.

40. Teh LS, Lai J-C, Lian JC. Rapidly developed multiple face and neck skin cancers in a patient with Sjögren's syndrome: A case report. $A m$ J Case Rep 2017; 18:347-350.

41. Lazarus $M N$, Robinson $D$, Mak $V$, et al. Incidence of cancer in a cohort of patients with primary Sjögren's syndrome. Rheumatology (Oxford) 2006; 45:1012-1015.

42. Leung J, Dowling L, Obadan I, et al. Risk of non-melanoma skin cancer in autoimmune hepatitis. Dig Dis Sci 2010; 55(11):3218-3223.

43. Lanoy E, Engels EA. Skin cancers associated with autoimmune conditions among elderly adults. Br J Cancer 2010; 103(1):112-114.

44. Nitsan Z, Kucuk N, Appel S, Tichmanovich N, Osherov M, Milo R. Mycosis fungoides - A cutaneous lymphoproliferative disorder in a patient treated with fingolimod for multiple sclerosis. J Clin Neurosci 2018; 48:102-103.

45. McCarthy EF. The toxins of William B. Coley and the treatment of bone and soft-tissue sarcomas. lowa Orthop J 2006; 26:154-158.

46. Coley WB. The treatment of malignant tumors by repeated inoculations of erysipelas: with a report of ten original cases. Am J Med Sci 1893; 105:487-511.

47. Urban JL, Schreiber H. Tumor antigens. Annu Rev Immunol 1992; 10:617-644.

48. Showalter A, Limaye A, Oyer JL, et al. Cytokines in immunogenic cell death: applications for cancer immunotherapy. Cytokine 2017; 97:123-132.

49. Sabado RL, Balan S, Bhardwaj N. Dendritic cell-based immunotherapy. Cell Research 2017; 27(1):74-95.
50. Mocellin S, Pasquali S, Rossi CR, et al. Interferon alpha adjuvant therapy in patients with high risk melanoma: a systematic review and meta-analysis. J Natl Cancer Inst 2010; 102:493-501.

51. Tsai KY. Systemic adjuvant therapy for patients with high-risk melanoma. Arch Dermatol 2007; 143:779-782.

52. Sadozai H, Gruber T, Hunger RE, Schenk M. Recent successes and future directions in immunotherapy of cutaneous melanoma. Front Immunol 2017; 8:1617.

53. Eggermont AM, Suciu S, Testori A, et al. Longterm results of the randomized phase III trial EORTC 18991 of adjuvant therapy with pegylated interferon alfa-2b versus observation in resected stage III melanoma. J Clin Oncol 2012; 30(31):3810-3818.

54. Petrella T, Quirt I, Verma $S$ et al. Single-agent interleukin-2 in the treatment of metastatic melanoma: a systematic review. Cancer Treat Rev 2007; 33(5):484-496.

55. Mouawad R, Sebert M, Michels J, Bloch J, Spano JP, Khayat D. Treatment for metastatic malignant melanoma: old drugs and new strategies. Crit Rev Oncol Hematol 2010; 74(1):27-39.

56. Seidel JA, Otsuka A, Kabashima K. Anti-PD-1 and anti-CTLA-4 therapies in cancer: mechanisms of action, efficacy, and limitations. Front Oncol 2018; 8:86.

57. Hodi FS, O'Day SJ, McDermott DF, et al. Improved survival with Ipilimumab in patients with metastatic melanoma. N Engl J Med 2010; 363(8):711-723.

58. Faries MB, Morton DL. Therapeutic vaccines for melanoma: current status. Bio Drugs 2005; 19(4):247-260.

59. Dalgleish AG. Therapeutic cancer vaccines: why so few randomized Phase III studies reflect the initial optimism of Phase II studies. Vaccine 2011; 29(47):8501-8505.

60. Perica K, Varela JC, Oelke M, Schneck J. Adoptive $\mathrm{T}$ cell immunotherapy for cancer. Rambam Maimonides Med J 2015; 6(1):e0004.

61. Johnson LA, Morgan RA, Dudley ME, et al. Gene therapy with human and mouse T-cell receptors mediates cancer regression and targets normal tissues expressing cognate antigen. Blood 2009; 114(3):535-546.

62. Berman B. Imiquimod: a new immune response modifier for the treatment of external genital warts and other diseases in dermatology. Int $J$ Dermatol 2002; 41(Suppl 1):7-11.

63. Neville JA, Welch E, Leffell DJ. Management of nonmelanoma skin cancer in 2007. Nat Clin Pract Oncol 2007; 4(8): 462-469. 
64. Gaspari AA, Sauder DN. Immunotherapy of basal cell carcinoma: evolving approaches. Dermatol Surg 2003; 29(10):1027-1034.

65. Stallone G, Infante B, Grandaliano G. Management and prevention of post-transplant malignancies in kidney transplant recipients. Clin Kidney J 2015; 8(5):637-644.

66. Tunçer Vural A, Karataş Toğral A, Kırnap M, Güleç AT, Haberal M. Skin cancer risk awareness and sun-protective behavior among solid-organ transplant recipients. Exp Clin Transplant 2018; 16 Suppl 1(Suppl 1):203-207.

67. Wu SZ, Jiang P, DeCaro JE, Bordeaux JS. A qualitative systematic review of the efficacy of sun protection education in organ transplant recipients. J Am Acad Dermatol 2016; 75(6):1238-1244. 